\title{
Cambrian (Furongian) rhynchonelliform brachiopods from the Eastern Alborz Mountains, Iran
}

\author{
LeOnid E. Popov, Mohammad-Reza Kebria-ee Zadeh, Mansoureh GHobadi Pour, \\ LARS E. HOLMER \& TATIANA L. MODZALEVSKAYA
}

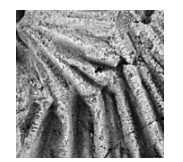

\begin{abstract}
The Cambrian (Furongian) shallow water carbonates in the Mila Formation in the Tuyeh-Darvar area (eastern Alborz, northern Iran) contain numerous shell beds, entirely composed of disarticulated valves of the billingsellide brachiopods Billingsella? fortis sp. nov. and Hyrcanostrophia tuyehensis gen. et sp. nov. Higher up in the Mila Formation, the shallow water carbonates are replaced by nodular limestones, deposited in an open marine environment, containing Palaeostrophia tecta Nikitin \& Popov, 1983 and the early polytoechioid Darvaretoechia prisca gen. et sp. nov. These two different brachiopod assemblages are assigned to the oligotaxic Billingsella and Palaeostrophia associations, respectively. These associations are considered to represent precursors to the brachiopod-dominated benthic assemblages of the Palaeozoic Evolutionary Fauna. The new brachiopod faunas from the Alborz Terrane are closely similar to contemporaneous Furongian faunas from the Australasian sector of Gondwana, in particular, to those from South China and the Kazakhstanian terranes. $•$ Key words: Furongian, Mila Formation, taxonomy, Billingsellida, Pentamerida.
\end{abstract}

Popov, L. E., Kebria-ee Zadeh, M.-R., Ghobadi Pour, M., Holmer, L.E. \& ModZalevskaya, T.L. 2013. Cambrian (Furongian) rhynchonelliform brachiopods from the Eastern Alborz Mountains, Iran. Bulletin of Geosciences 88(3), 525-538 (7 figures, 4 tables). Czech Geological Survey, Prague. ISSN 1214-1119. Manuscript received November 1, 2012; accepted in revised form February 5, 2013; published online April 5, 2013; issued July 3, 2013.

Leonid E. Popov, Department of Geology, National Museum of Wales, Cathays Park, Cardiff CF10 3NP, United Kingdom; leonid.popov@museumwales.ac.uk Mohammad-Reza Kebria-ee Zadeh, Department of Geology, Payame Noor University, Semnan, Iran; mkebria_ee@hotmail.com•Mansoureh Ghobadi Pour, Department of Geology, Faculty of Sciences, Golestan University, Gorgan 49138-15739, Iran; mghobadipour@yahoo.co.uk • Lars E. Holmer, Department of Earth Sciences, Palaeobiology, Villav. 16, 75236 Uppsala, Sweden; Lars.Holmer@pal.uu.se•Tatiana L. Modzalevskaya, Department of Stratigraphy and Palaeontology, Russian Geological Research Institute (VSEGEI), 74 Sredniy prospect, 199106 St.Petersburg, Russia; Tatiana_Modzalevskaya@vsegei.ru

Late Cambrian (Furongian) rhynchonelliform brachiopods are generally poorly known and usually considered to be of relatively minor importance. However, billingsellides, and to a lesser extent syntrophiidine brachiopods, dominate in early Furongian low diversity brachiopod associations in shallow carbonate and clastic shelf environments of temperate and low latitude peri-Gondwana (Nikitin 1956, Bassett et al. 2002, Zhan et al. 2010, Popov et al. 2011). In the Alborz Region (Mila Formation) and Central Iran (Derenjal Formation), disarticulated billingsellide shells often form extensive shell beds within carbonate shoal complexes. More than half a century ago, Stöcklin et al. (1964) listed Billingsella as the most characteristic fossil in the middle to upper Cambrian Mila Formation in Alborz. Indeed, billingsellides are the most common fossil in the Furongian Member 3 of the Mila Formation in the eastern Alborz Mountains, where, as noted above, they form extensive shell beds. Two recently published papers on the Cambrian (Furongian) brachiopods of northern Iran were dedicated to micro- morphic linguliform brachiopods (Popov et al. 2009) from the Simeh-Kuh section, north-west of Damghan, and a small fauna of silicified brachiopods (mostly early pentamerides of the Superfamily Syntrophioidea) from the upper Furongian Alborsella trilobite biozone of the DehMolla section, west of the city of Shahrud (Popov et al. 2011), both in the eastern Alborz Mountains. However, the billingsellides have not previously been described.

The main object of this paper is to describe new brachiopod fauns from the Mila Formation members 3 and 4 of the Tuyeh-Darvar Section in the eastern Alborz Mountains, northern Iran, assembled during several field seasons from 2009 and 2011. An important part of the collection comprises the billingsellide-dominated shell-beds from five fossiliferous horizons in the Mila Formation Member 3, which include the species Billingsella? fortis sp. nov. and Hyrcanostrophia tuyehensis sp. nov. A single fossiliferous horizon in the middle part of the overlying Mila Formation Member 4 contains a different faunal association, 


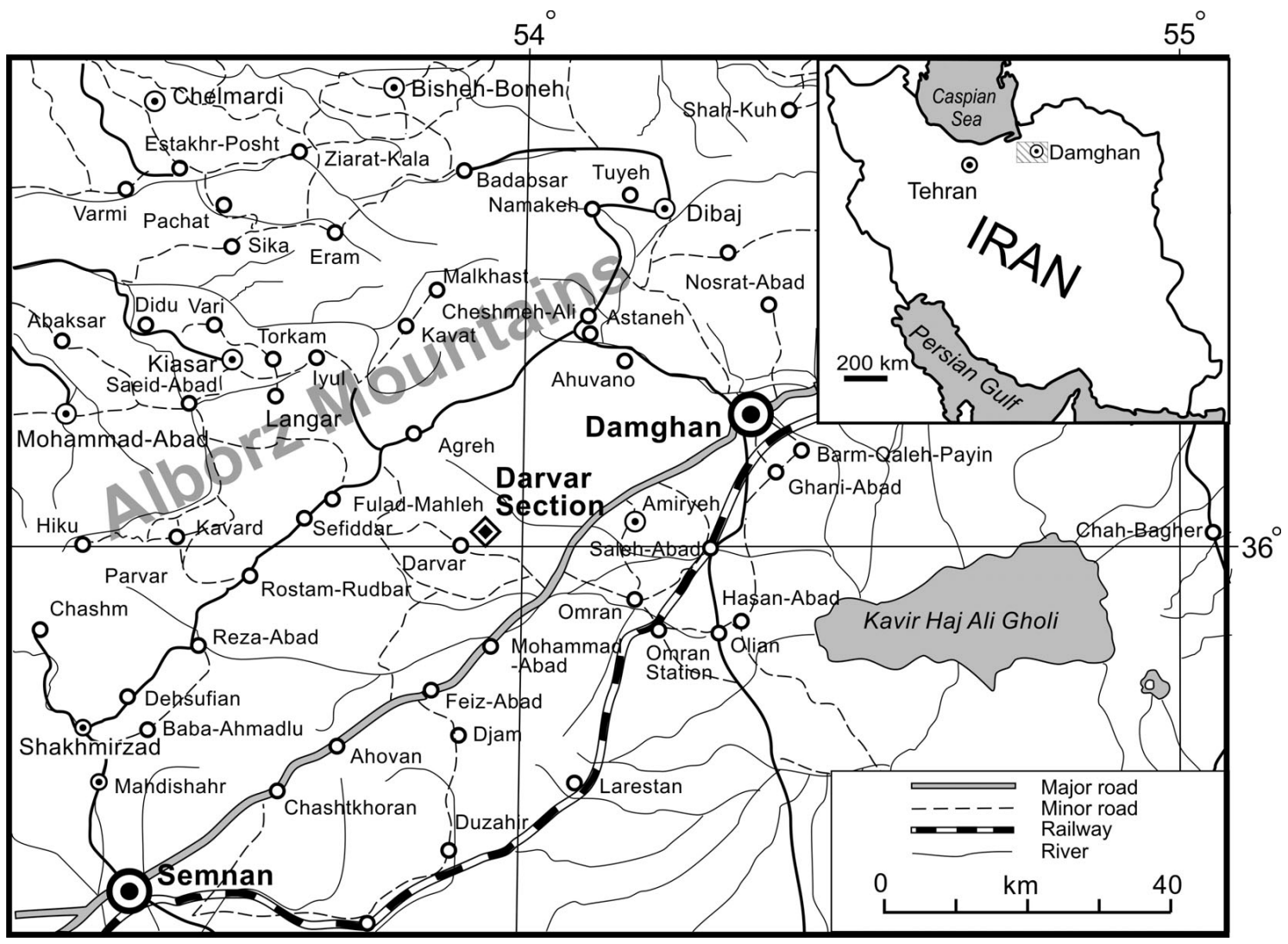

Figure 1. Geographical map showing the position of the Tuyeh-Darvar area, west of Damghan, northern Iran.

including the earliest polytoechiid Darvaretoechia prisca gen. et sp. nov. and the syntrophiidine Palaeostrophia tecta Nikitin \& Popov, 1983.

\section{Geological and geographical setting}

The studied Cambrian section is situated about $1 \mathrm{~km}$ northeast of the village of Tuyeh, about $48 \mathrm{~km}$ south-west of Damghan (Fig. 1). The stratigraphy and lithofacies of the lower part of the Cambrian succession in the Tuyeh-Darvar area were outlined by Lasemi \& Amin-Rasouli (2007). The middle to upper part of this Cambrian succession is assigned to the Mila Formation. In the Tuyeh-Darvar section the Mila Formation rests disconformably on the lower Cambrian Lalun Formation, and is overlain unconformably by the Upper Devonian Jeirud Formation. Stöcklin et al. (1964) informally subdivided the Mila Formation into members 1-5.

The geographical coordinates of the base of the measured section at the base of the Mila Formation Member 3 are: $36^{\circ} 01^{\prime} 22.1^{\prime \prime} \mathrm{N}$ and $53^{\circ} 52^{\prime} 26^{\prime \prime} \mathrm{E}$ at $1698 \mathrm{~m}$ above sea level. Here the Mila Formation Member 3 is about $60 \mathrm{~m}$ thick. It comprises bioclastic echinoderm limestones, intercalating with numerous shell beds entirely composed of disarticulated Billingsella; these beds were deposited in a high energy shallow marine environment, probably representing carbonate shoal complexes (Hosseini et al. 2010). Brachiopods were sampled from six fossiliferous horizons as shown on Fig. 2. Their geographical location is as follows:

Sample M2D [36 $01^{\prime} 22.1^{\prime \prime} \mathrm{N}, 53^{\circ} 52^{\prime} 25.9^{\prime \prime} \mathrm{E}$, altitude $1704 \mathrm{~m}]$ is from bioclastic limestone with abundant echinoderm ossicles and shell fragments of Billingsella, and a few disarticulated valves of Palaeostrophia cf. orthia (Walcott, 1905).

Sample M4D [36 $01^{\prime} 21.4^{\prime \prime} \mathrm{N}, 53^{\circ} 52^{\prime} 25.9^{\prime \prime} \mathrm{E}$, altitude $1705 \mathrm{~m}]$ is a shell bed formed by accumulation of disarticulated, mainly broken valves of Hyrcanostrophia tuyehensis gen. et sp. nov.

Sample M5D [36 $01^{\prime} 21.4^{\prime \prime} \mathrm{N}, 53^{\circ} 52^{\prime} 26.1^{\prime \prime} \mathrm{E}$, altitude $1696 \mathrm{~m}$ ] is from bioclastic limestone with a few shells of Billingsella? fortis sp. nov.

Samples M6D [36 $6^{\circ} 01^{\prime} 21.6^{\prime \prime} \mathrm{N}, 53^{\circ} 52^{\prime} 26.2^{\prime \prime} \mathrm{E}$, altitude $1705 \mathrm{~m}$ ], M8D [36 $01^{\prime} 21.3^{\prime \prime} \mathrm{N}, 53^{\circ} 52^{\prime} 26.1^{\prime \prime} \mathrm{E}$, altitude $1706 \mathrm{~m}$ ] and M8-D10 [36 $01^{\prime} 21.4^{\prime \prime} \mathrm{N}, 5^{\circ} 52^{\prime} 26.5^{\prime \prime} \mathrm{E}$, altitude $1705 \mathrm{~m}$ ] are from shell beds formed by disarticulated valves of Billingsella? fortis and Hyrcanostrophia tuyehensis.

Mila Formation Member 4 is about 110 m thick in the measured section. It comprises several units of bioclastic 
and nodular limestones separated by beds of argillite and siltstone in the lower part, and intercalating argillite, siltstone and fine-grained sandstone in the upper part (Fig. 2).

Sample M4/3TD [geographic coordinates $36^{\circ} 01^{\prime} 27^{\prime \prime} \mathrm{N}$, $\left.53^{\circ} 52^{\prime} 36^{\prime \prime} \mathrm{E}\right]$ is from the uppermost unit of limestone. It contains numerous articulated shells of Darvaretoechia prisca gen. et sp. nov. and Palaeostrophia tecta Nikitin \& Popov, 1983. The overlying argillite of the Mila Formation Member 4 (sample M4/4TD) contains abundant trilobites, including Charchaquia sp. and Mictosaukia sp.

\section{Biostratigraphical and palaeobiogeographical significance}

The low diversity Furongian brachiopod faunas from the Mila Formation members 3 and 4 are dominated by species of Billingsella and Palaeostrophia, which are common elements of the pan-tropical fauna and occur also in Laurentia (Ulrich \& Cooper 1938, Freeman \& Stitt 1996) and the tropical peri-Gondwana, including associated plates and island arcs (Nikitin 1956, Holmer et al. 2001, Hughes et al. 2010, Zhan et al. 2010, Popov et al. 2011). All billingsellide species documented from the Furongian of Alborz are endemic. However, the recorded syntrophiidine species have a wider geographical distribution within Australasian peri-Gondwana. In particular, Palaeostrophia cf. orthia (Walcott, 1905) is probably conspecific with forms occurring in the upper part of the Furongian (Cambrian) of the Shandong Province, North China (Walcott 1912, Ulrich \& Cooper 1938), whereas Palaeostrophia tecta, from the Mila Formation Member 4, has also been reported from the uppermost Furongian Euloma limataris-Taoyuania Beds of the Batyrbai section in the Malyi Karatau Range, Kazakhstan (Nikitin \& Popov 1983, Holmer et al. 2001). Nevertheless, our poor general knowledge of the Furongian Australasian brachiopods and the absence of chronostratigraphically informative species of trilobites and conodonts in the Tuyeh-Darvar section make it difficult to provide a detailed correlation with the Furongian sequences outside Iran.

Bassett et al. (2002) suggested that the brachiopod dominated benthic associations, including the Billingsella Association that evolved in the shallow shelves of Gondwana during the Furongian can be regarded as precursors of the Palaeozoic Evolutionary fauna, and they are comparable in taxonomic composition and trophic structure.

In Tuyeh-Darvar, the Billingsella Association is confined to Mila Formation Member 3 and includes Billingsella? fortis and Hyrcanostrophia tuyehensis. The abundance of billingsellide shells declined significantly in the bioclastic echinoderm limestone (containing eocrinoid ossicles) in the lower part of Member 3 (sample M2-D); here

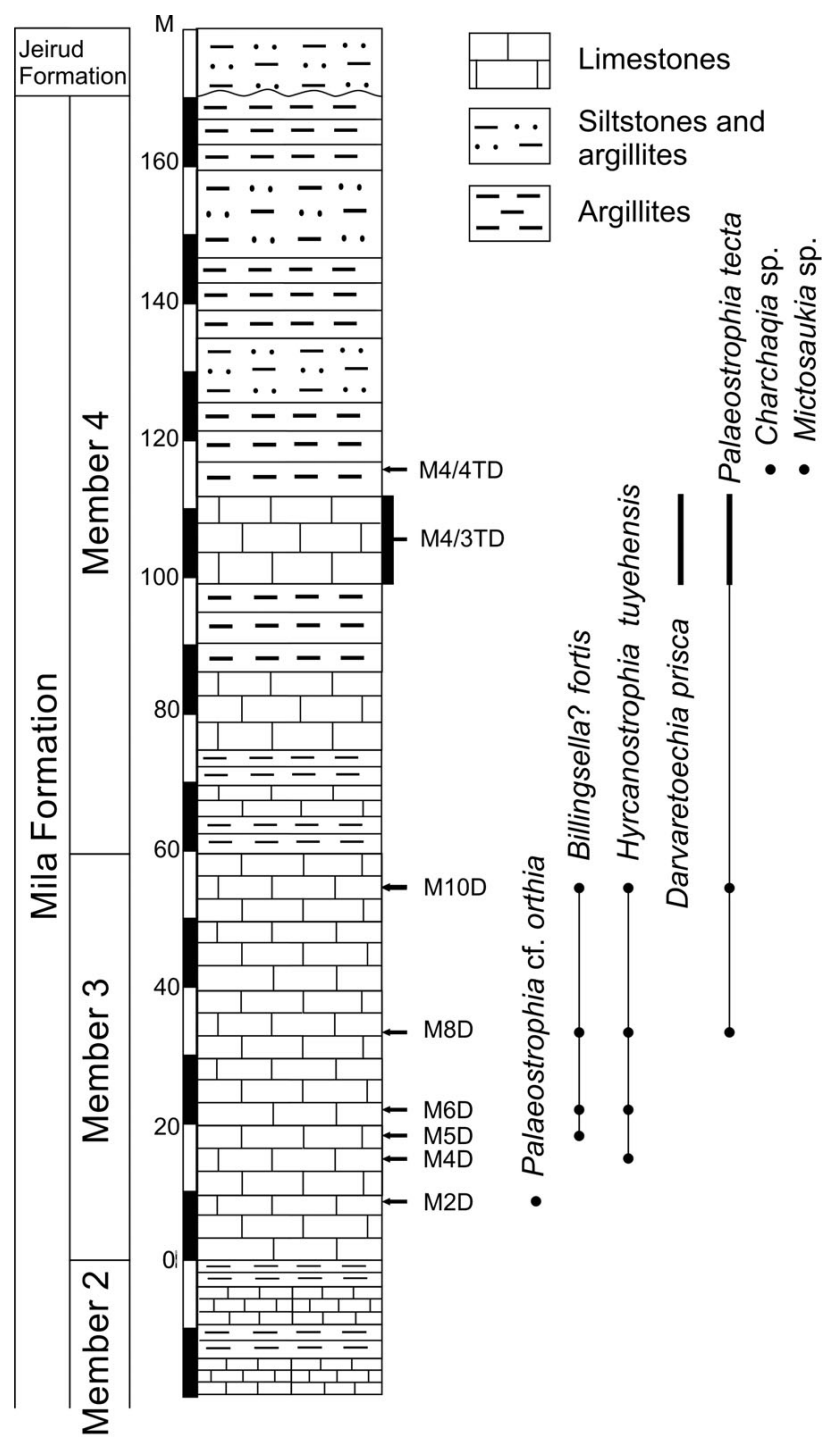

Figure 2. Stratigraphical column of the Cambrian (Furongian) succession in the Tuyeh-Darvar section showing position of samples and stratigraphical distribution of brachiopods and trilobites.

brachiopods are mainly represented by disarticulated valves of the syntrophiidine Palaeostrophia cf. orthia.

Higher up in Member 4 of the Mila Formation, the Billingsella Association is replaced by the syntrophiidine Palaeostrophia association with $P$. tecta as an important component. These brachiopods inhabited a quiet offshore environment, probably equivalent to Benthic Assemblage 3 , and they are mostly preserved as articulated valves. Eocrinoid ossicles are common, but trilobites are almost completely absent. This fauna can be compared with the Palaeostrophia-Plectotrophia Association of the uppermost Furongian in the Deh-Molla section of eastern Alborz, Iran (Popov et al. 2011) and the Billingsella-Palaeostrophia Association recently described by Zhan et al. (2010) from the Furongian, Guole Formation of South 
China, but the studied assemblage differs from both in having a lower taxonomic diversity. Remarkably, the late Furongian faunas of Alborz and South China include Darvaretoechia gen. nov., which is the earliest and so far only known Cambrian representative of the Superfamily Polytoechioidea. This can be taken as additional evidence for the close affinities of the Furongian faunas of the Alborz terrane and South China revealed earlier from the analysis of contemporaneous trilobite faunas by Peng et al. (1999). Polytoechioids became distinct components of the early to mid-Ordovician brachiopod assemblages in Gondwana and Laurentia.

\section{Systematic palaeontology}

Abbreviations for parameters measured (in millimetres) on specimens are: W, L, T - maximum width, length, thickness of the shell; Lv, Ld - maximum length of ventral and dorsal valve; Iw, Il - maximum width and length of interarea; $\mathrm{Sw}$ - width of median fold and sulcus; Ml, Mw - length and width of ventral muscle field; $\mathrm{X}$ - mean; $\mathrm{S}$ - standard deviation from the mean; $\mathrm{N}$ - number of specimens; max - maximum observed size; min - minimum observed size.

All brachiopod specimens described here are housed in the Department of Geology, National Museum of Wales, UK; Accession Number NMW 2011.16G.

Order Billingsellida Schuchert, 1893

Superfamily Billingselloidea Schuchert, 1893

Family Billingsellidae Schuchert, 1893

\section{Genus Billingsella Hall \& Clarke, 1892}

Type species. - Original designation by Hall \& Clarke (1892): Orthis pepina Hall, 1863, Upper Cambrian, Potsdam Sandstone, New York State, USA.

Remarks. - As presently defined, Billingsella can be considered as a 'waste basket taxon' with many species assigned to the genus being inadequately known. Walcott (1912) considered the type species Billingsella pepina to be a junior subjective synonym of Billingsella coloradoensis (Shumard, 1860); however, the types and topotypes of Billingsella pepina were not available to Walcott in his revision of Billingsella. Schuchert \& Cooper (1932) considered Billingsella pepina as a separate species; however the specimens, illustrated in their monograph (Schuchert \& Cooper 1932, pl. 1, figs 6, 13, 19, 21, 25) do not represent topotypes, and according to the later revision by Ulrich \& Cooper (1938) they belong to Billingsella perfecta Ulrich \& Cooper, 1936. Bell \& Ellinwood (1962, p. 411) noted that Billingsella pepina was poorly understood; however they assumed that Billingsella pepina, Billingsella coloradoensis and Billingsella perfecta could represent geographic varieties of the same species. The problems surrounding the type species of Billingsella were also addressed by Freeman \& Stitt (1996).

Another important issue is that previous studies commonly misinterpreted the morphology of the ventral valve of Billingsella; this mainly resulted from the erroneous description by Schuchert \& Cooper (1932, p. 48), who listed strong, widely divergent dental plates among diagnostic features of the genus. It is true that widely divergent ridges developed as teeth-supporting structures in some billingsellide species, e.g. Billingsella texana Bell (Bell \& Ellinwood, 1962, pl. 62, fig. 13); however, these ridges are placed entirely at the bottom of the mantle cavity and are not confined to the boundaries of the visceral area (ventral muscle field) as true dental plates in the orthides and the advanced billingsellide Superfamily Polytoechioidea. Consequently the teeth-supporting ridges in some Billingsella cannot be considered as homologous to the dental plates (for further discussion see Nikitin 1956; Popov et al. 2001, 2011).

The Australasian Billingsella species (Nikitin 1956, Hughes et al. 2010, Zhan et al. 2010, Popov et al. 2011) are often up to twice as large as the Laurentian species of the genus and exhibit remarkable diversity in such features as relative valve convexity and profile, radial ornament, shape and size of the notothyrial platform, and characters of socket ridges. It is probable that at least some of these species are not congeneric with the type species of Billingsella; however, pending its revision, the taxa described below are provisionally retained within the genus. Kobayashi (1933) and Endo \& Resser (1937) briefly described and illustrated a number of Billingsella species from Shandong and Liaoning provinces of North China. We agree with Hughes et al. (2010) that these taxa are too briefly characterized and poorly illustrated for comparison to other Billingsella species. In addition, generic affiliation of Billingsella pumpellyi Walcott, 1905, is highly questionable and it may represent an early orthide.

\section{Billingsella? fortis sp. nov.}

Figures 3A-L, 4A, B; Table 1

Derivation of name. - Latin fortis - strong, sturdy, after robust, coarsely ribbed shell.

Holotype. - NMW 2011.16G.381, dorsal valve, Furongian, Mila Formation (Member 3), sample M5D, Tuyeh-Darvar section, Alborz Mountains, Iran.

Paratypes. - Sample M5D, one ventral valve (NMW 2011.16G.378); sample M6D, four ventral valves (NMW 

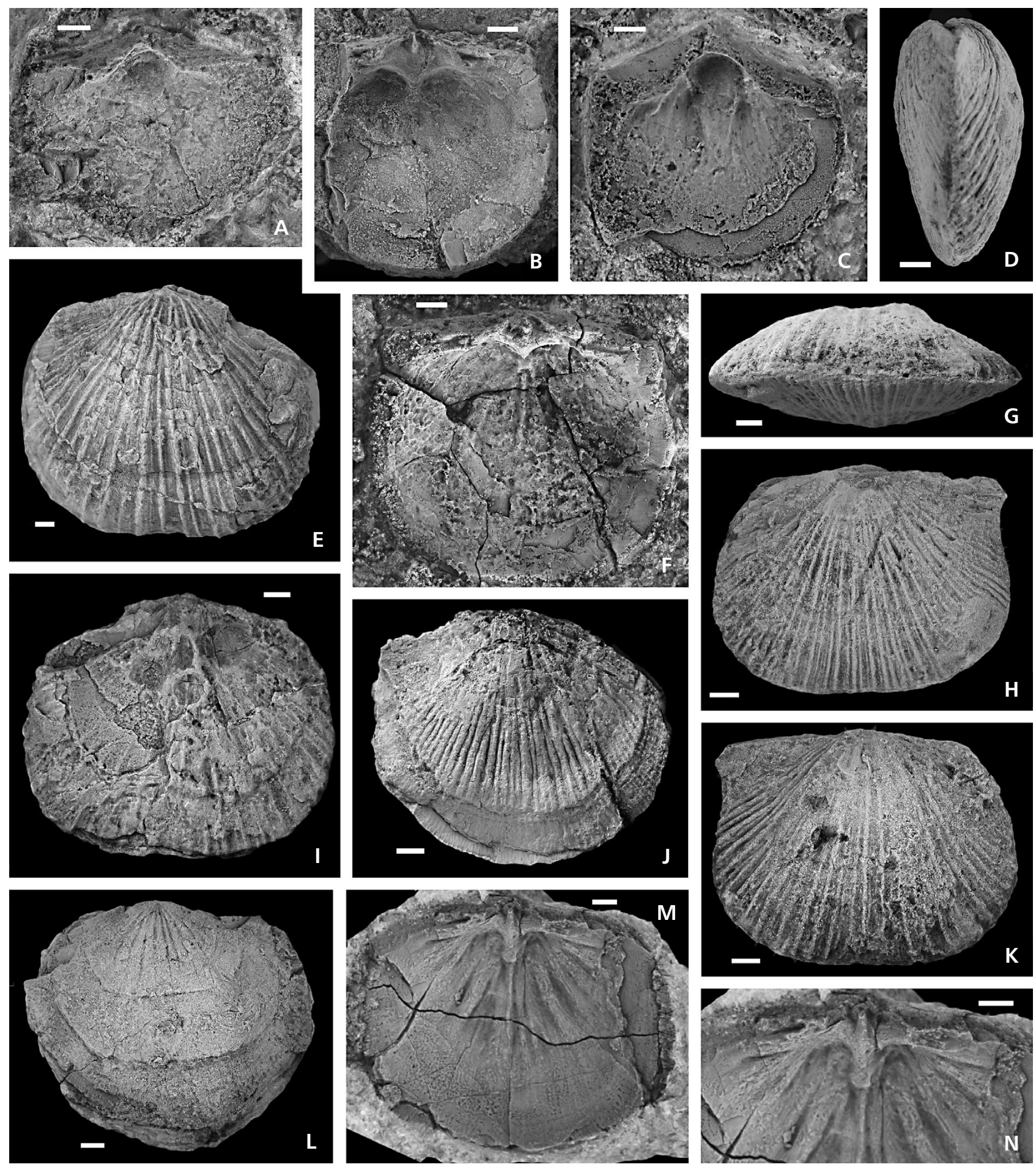

Figure 3. A-L - Billingsella? fortis sp. nov. • A - NMW 2011.16G.378, ventral valve interior, sample M(6-8)D. • B - NMW 2011.16G.377, dorsal valve interior, sample M(6-8)D. • C - NMW 2011.16G.379, ventral valve interior, sample M(6-8)D. • D, G, H, K - NMW 2011.16G.380, conjoined valves lateral, dorsal, anterior and ventral views, sample M(6-8)D. • F - NMW 2011.16G.381, holotype, dorsal valve interior, sample M5D. • E, I - NMW 2011.16G.382, ventral and dorsal view of conjoined valves, sample M(6-8)D. • J - NMW 2011.16G.383, ventral view of conjoined valves, sample M(6-8)D. • L - NMW 2011.16G.384, dorsal valve exterior, sample M(6-8)D. • M, N - Hyrcanostrophia tuyehensis gen. et sp. nov.; sample M(6-8) D; NMW 2011.16G.356, holotype, dorsal valve interior and detail of cardinalia. All scale bars are $2 \mathrm{~mm}$. 
Table 1. Basic statistics of two articulated shells, four ventral and ten dorsal valves of Billingsella fortis sp. nov. from Member 3 of Mila Formation.

\begin{tabular}{lrrrrrrcc}
\hline & $\mathrm{Lv}$ & $\mathrm{W}$ & $\mathrm{Lv} / \mathrm{W}$ & $\mathrm{Ld}$ & $\mathrm{W}$ & $\mathrm{T}$ & $\mathrm{Ld} / \mathrm{W}$ & $\mathrm{T} / \mathrm{Ld}$ \\
\hline $\mathrm{n}$ & \multicolumn{1}{c}{6} & \multicolumn{1}{c}{5} & 5 & 12 & 12 & 11 & 10 & 8 \\
$\mathrm{x}$ & 17.6 & 19.1 & $88.1 \%$ & 16.3 & 19.1 & 4.2 & $85.1 \%$ & $25.5 \%$ \\
$\mathrm{~s}$ & 3.7 & 3.6 & 12.2 & 1.9 & 1.5 & 1.15 & 5.5 & 4.9 \\
$\min$ & 12.2 & 14.5 & $75.8 \%$ & 13.0 & 16.6 & 2.3 & $76.5 \%$ & $17.7 \%$ \\
$\max$ & 22.4 & 23.2 & $106.2 \%$ & 19.3 & 21.0 & 5.8 & $95.5 \%$ & $30.8 \%$ \\
\hline
\end{tabular}

2011.16G.423-426), three dorsal valves (NMW 2011.16G.427-429); sample M8D, three dorsal valves (NMW 2011.16G.414-416); sample M8D, two ventral valves (NMW 2011.16G.418, 419); sample M(6-8)D (loose sample); three articulated shells (NMW 2011.16G.380, 382, 383), two ventral valves (NMW 2011.16G.378, 379), nine dorsal valves (NMW 2011.16G.376, 377, 384, 434-439, 459, 460); sample M9-D, one dorsal valve (NMW 2011.16G.460); sample M10-D; two ventral valves (NMW 2011.16G.417.1, 2); one dorsal valve (NMW 2011.16G.417.3); in total, comprising three articulated shells, 11 ventral and 18 dorsal valves.

Diagnosis. - Dorsibiconvex, transverse, subrectangular shell with gently sulcate to rectimarginate anterior commissure and with shallow sulcus fading anterior to mid length. Radial ornament coarsely costellate, with 3-6 ribs per $3 \mathrm{~mm}$, increasing in number mainly by intercalation. Ventral muscle field strongly thickened, but not defined by distinct rim anteriorly. Dorsal interior with wide, blade-like socket ridges and high, rhomboidal notothyrial platform, bisected by blade-like cardinal process in posterior half and supported anteriorly by short median ridge.

Description. - Shell dorsibiconvex, about $45 \%$ as thick as long, slightly transverse, subrectangular, about $88 \%$ $(\mathrm{S}=12, \mathrm{~N}=5)$ as long as wide, with maximum width at or slightly anterior to hinge line. Cardinal extremities slightly acute to almost right angled; anterior commissure gently sulcate to rectimarginate. Lateral profile of ventral valve moderately convex with maximum height at one-third valve length from umbo (Fig. 3D). Ventral interarea high, triangular, planar, apsacline with convex pseudodeltidium covering about two-thirds of delthyrium (Fig 3A, C). Dorsal valve relatively strongly and evenly convex, about $85 \%$ $(\mathrm{S}=5.6, \mathrm{~N}=15)$ as long as wide and $25.5 \%(\mathrm{~S}=4.9$, $\mathrm{N}=11$ ) as deep as long. Dorsal interarea planar, apsacline with broad, convex chilidium (Fig. 3B, F). Dorsal sulcus shallow, originating at umbo and fading anterior to mid length (Fig. 3G, H). Radial ornament costellate with strong ribs, 3-6 per $3 \mathrm{~mm}$ along anterior margin, separated by broad interspaces and increasing in number mainly by intercalation (Fig. 3E, H, K). Concentric ornament poorly developed with faint, evenly spaced filae and occasional growth lamellae.

Ventral interior with strong, widely spaced, transverse teeth. Ventral muscle field strongly thickened, but not defined by distinct rim anteriorly, with adductor scars about twice as long as narrow, weakly impressed diductor scars (Fig. 3A, C). Impressions of mantle canals not discernible. Dorsal valve with wide, blade-like socket ridges slightly inclined to hinge line. Notothyrial platform high, transverse, rhomboidal, supported anteriorly by very short median ridge and bisected by simple, blade-like cardinal process in posterior half. Dorsal adductor muscle field not impressed, discernible only in gerontic specimens (Fig. 3F).

Remarks. - In having coarse radial ornament, a weak dorsal median sulcus, a high notothyrial platform and broad socket ridges inclined slightly to the hinge line, Billingsella? fortis is similar to Billingsella cf. tonkiniana Mansuy, 1915 from the Chekha Formation (Furongian) of Bhutan (Hughes et al. 2010) and Billingsella borukaevi Nikitin, 1956 from the Kuyandy Formation of the Boshchekul Region in north-eastern Central Kazakhstan. It differs from Billingsella cf. tonkiniana in having a considerably lower ventral interarea, and in the complete absence of a ventral median fold, whereas Billingsella borukaevi has an almost flat ventral valve and a narrow subtriangular notothyrial platform unlike Billingsella? fortis.

\section{Genus Hyrcanostrophia gen. nov.}

Derivation of name. - After Hyrcania, ancient name for the South Caspian Region in Greek literature.

Figure 4. A, B - Billingsella? fortis sp. nov. • A - NMW 2011.16G.376, dorsal valve interior, sample M(6-8)D. • B - NMW 2011.16G.459, dorsal valve interior, sample M(6-8)D. • C-O - Hyrcanostrophia tuyehensis gen. et sp. nov., sample M8D. • C - NMW 2011.16G.363, dorsal valve interior, sample M8-D. • D, E - NMW 2011.16G.357, conjoined valves ventral and dorsal views, sample M4D. • F - NMW 2011.16G.366, ventral valve exterior, sample M9D.•G - NMW 2011.16G.366, ventral valve exterior, sample M9D, dorsal valve exterior, sample M9D. • H - NMW 2011.16G.369, ventral valve interior, sample M(6-8)D. • I - NMW 2011.16G.370, ventral internal mould, sample M(6-8)D. • J - NMW 2011.16G.365, dorsal valve interior, sample M11-D. • K - NMW 2011.16G.372, dorsal valve exterior, sample M(6-8)D. • L - NMW 2011.16G.375 dorsal valve interior, sample M6D. • M - NMW 2011.16G.373, ventral valve exterior, sample M(6-8)D. • N - NMW 2011.16G.374, ventral valve exterior, and NMW 2011.16G.458, dorsal valve exterior, sample M(6-8)D. • O - NMW 2011.16G.371, dorsal valve interior, sample M(6-8)D. • P - Darvaretoechia prisca gen. et sp. nov.; NMW 2011.16G.461, dorsal valve interior, sample M4/3TD. All scale bars $2 \mathrm{~mm}$. 

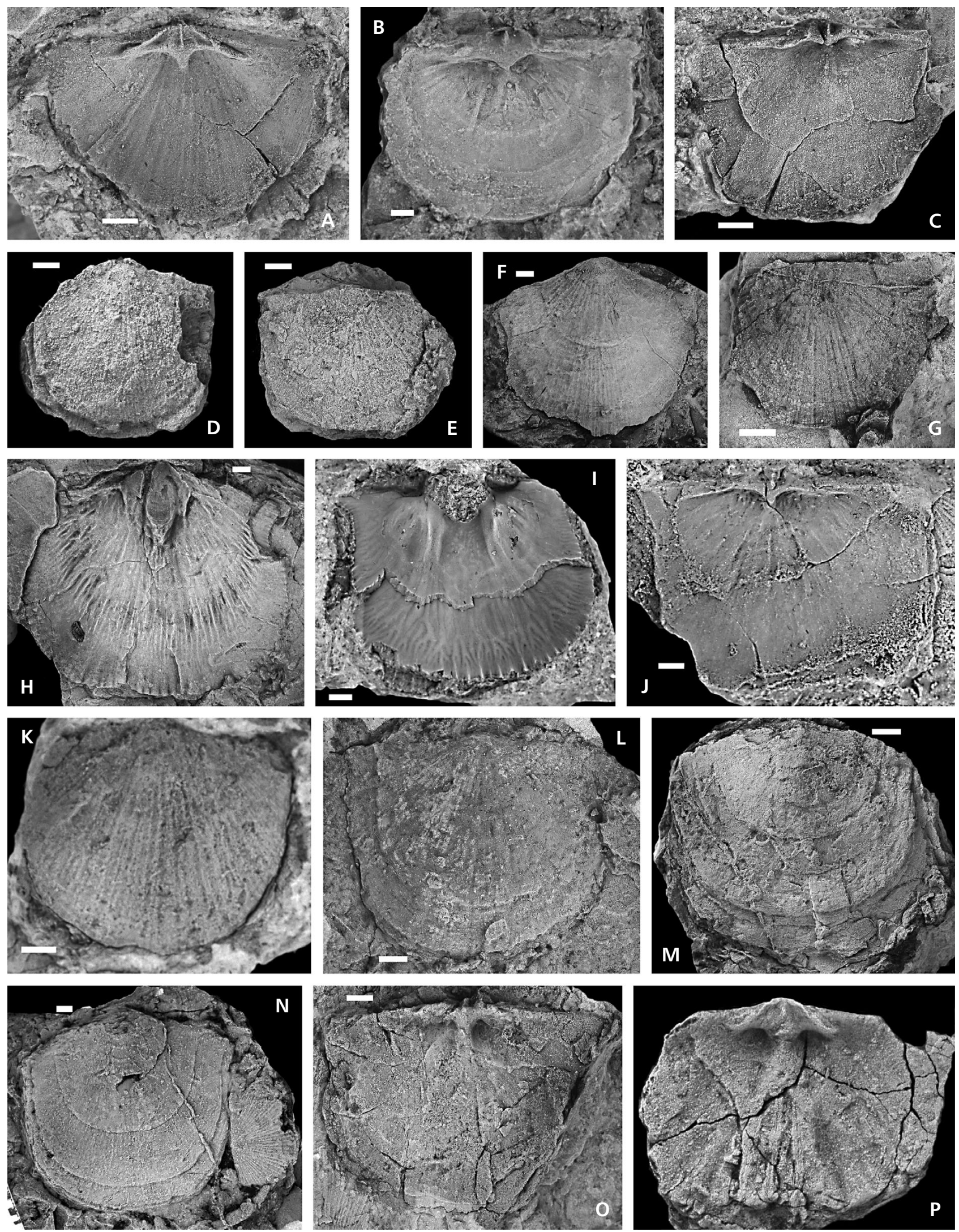
Table 2. Basic statistics of 12 ventral and 11 dorsal valves of Billingsella fortis sp. nov. from Member 3 of Mila Formation.

\begin{tabular}{lcccccc}
\hline & Lv & W & Lv/W & Ld & W & Ld/W \\
\hline $\mathrm{n}$ & 12 & 11 & 12 & 11 & 11 & 11 \\
$\mathrm{x}$ & 20.7 & 21.85 & $95.5 \%$ & 18.2 & 21.7 & $85.1 \%$ \\
$\mathrm{~s}$ & 4.0 & 4.6 & 8.3 & 4.5 & 5.3 & 5.5 \\
$\min$ & 12.9 & 14.1 & $85.9 \%$ & 8.9 & 9.8 & $76.5 \%$ \\
$\max$ & 27.4 & 31.9 & $115.0 \%$ & 24.4 & 27.2 & $95.5 \%$ \\
\hline
\end{tabular}

Type species. - Hyrcanostrophia tuyehensis sp. nov. from the Cambrian, Furongian, Mila Formation of the Alborz Mountains, Northern Iran.

Diagnosis. - Convexoplane shell with rectimarginate anterior commissure. Ventral interarea almost orthocline with broad convex deltidium. Dorsal interarea low anacline with well developed chilidium. Radial ornament multicostellate with flattened ribs separated by narrow interspaces. Ventral interior with transverse teeth supported by callus of secondary shell. Ventral muscle field on pseudospondylium. Ventral mantle canals saccate. Dorsal interior with broad, subtriangular notothyrial platform steeply inclined posteriorly. Cardinal process simple, ridge-like. Socket ridges as low, narrow knobs on thickened inner side of dorsal interarea, bounding shallow, transverse sockets facing posteriorly. Dorsal adductor muscle scars radially arranged, separated by faint myophragms.

Remarks. - Hyrcanostrophia differs from the typical Laurentian Billingsella, e.g. Billingsella coloradoensis (Shumard, 1860) as revised by Bell \& Ellinwood (1962), Billingsella perfecta Ulrich \& Cooper, 1936, Billingsella corrugata Ulrich \& Cooper, 1936 and Billingsella texana Bell \& Ellinwood, 1962, in having narrow, rudimentary socket ridges and in having a planoconvex transverse shell profile, with the ventral valve being almost flat. Hyrcanostrophia is also significantly larger and completely lacks a ventral fold, whereas the dorsal median sulcus is poorly developed to almost absent.

Hyrcanostrophia differs from other billingsellid genera, including Cymbithyris Cooper, 1952; Kozhuchinella Severgina, 1967; Saccogonum Havlíček, 1971 and Xenorthis Ulrich \& Cooper, 1936, in having a convexoplane shell, an orthocline ventral interarea, multicostellate radial ornament and rudimentary socket plates; it also has a chilidium, unlike Saccogonum, and a rectimarginate anterior commissure unlike Xenorthis.

Species assigned. - In addition to the type species, the following species can be assigned to Hyrcanostrophia: Billingsella lingulaeformis Nikitin, 1956, from the Cambrian (Furongian) Kuyandy Formation of the Boshchekul Re- gion, Central Kazakhstan; Billingsella lingulaeformis var. seletensis Nikitin, 1956, from the Cambrian (Furongian) Selety Limestone of the Selety River Basin, Kazakhstan; and Billingsella aff. seletensis Nikitin, 1956, from the Cambrian (Furongian) Member 4 of the Mila Formation, Deh-Molla section, eastern Alborz, Iran (Popov et al. 2011).

\section{Hyrcanostrophia tuyehensis sp. nov.}

Figures 3M, N, 4C-O; Table 2

Derivation of name. - After Tuyeh village near the type locality.

Holotype. - NMW 2011.16G.356, dorsal valve, Furongian, Mila Formation (Member 3), sample M(6-8)D, TuyehDarvar section, Alborz Mountains, Iran.

Paratypes. - Sample M4D, three articulated shells [NMW 2011.16G.357 ( $\mathrm{Lv}=12.7, \mathrm{Ld}=10.9, \mathrm{~W}=14.1, \mathrm{~T}=3.8)$, 358,359 ], one ventral valve (NMW 2011.16G.360); sample M6D, one dorsal valve (NMW 2011.16G. 375); sample M8D, three ventral valves [NMW 2011.16G.361 (Lv = 27.3, $\mathrm{W}=32.2), 362$ ( $\mathrm{Lv}=16.1, \mathrm{~W}=18.9), 362]$, two dorsal valves (NMW 2011.16G.363, 364); sample M9D, two ventral valves (NMW 2011.16G.366, 368), one dorsal valve (NMW 2011.16G.367); sample M(6-8)D (loose sample), 13 ventral valves (NMW 2011.16G.369, 370; 373, 374, 399-402, 445-449), 22 dorsal valves (NMW 2011.16G.371, 372, 385-398, 440-444, 458); in total, comprising three articulated shells, 19 ventral and 27 dorsal valves.

Diagnosis. - Convexoplane shell, almost as wide as long, with rectimarginate anterior commissure. Ventral interarea almost orthocline. Radial ornament multicostellate with 8-10 flattened ribs per $3 \mathrm{~mm}$ separated by narrow interspaces. Ventral muscle field on pseudospondylium, extending anteriorly about two-fifths of total valve length. Socket ridges forming low and narrow knobs.

Description. - Shell convexoplane, subpentagonal, about $95 \%(\mathrm{~S}=8.3, \mathrm{~N}=12)$ as long as wide with maximum width at hinge line. Cardinal extremities slightly acute to almost right angled; anterior commissure uniplicate. Ventral valve almost flat with slightly raised, pointed umbo and with maximum height in umbonal area. Ventral interarea high, triangular, planar, almost orthocline with broad, convex pseudodeltidium (Fig. 4E). Dorsal valve moderately and evenly convex, about $84 \%(\mathrm{~S}=4.1, \mathrm{~N}=11)$ as long as wide. Dorsal interarea low, planar, strongly apsacline, with low, convex chilidium (Figs 3M, N, 4J, O, P). Radial ornament costellate with high rounded ribs about 8-10 per $3 \mathrm{~mm}$ along anterior margin, separated by narrow interspaces 
and increasing in number by intercalation or bifurcation; concentric ornament of up to six growth lamellae in anterior half of shell (Fig. 4C, G, K, M).

Ventral interior with strong, transverse teeth, with muscle field raised anteriorly on pseudospondylium which occupies about two-fifths of total length of valve (Fig. 4H, I). Ventral adductor muscle scar broad, subtriangular, significantly longer than narrow, strongly impressed diductor scars (Fig. 4H). Ventral mantle canals saccate with widely spaced, almost parallel vascula media (Fig. 4I). Dorsal interior with broad, subtriangular notothyrial platform steeply inclined posteriorly and bisected by simple, ridge-like cardinal process. Socket ridges forming low, narrow knobs supported by callus on thickened inner side of dorsal interarea, subparallel to hinge-line and bounding shallow, transverse sockets which face posteriorly (Figs 3M, N, 4A, B, J). Dorsal adductor muscle scars weakly impressed, radially arranged. Dorsal median ridge broad and short, and in gerontic specimens, merging anteriorly with faint myophragm bisecting adductor muscle field (Fig. 3M, N).

Remarks. - Hyrcanostrophia tuyehensis is similar to specimens from Member 4 of the Mila Formation in the Deh-Molla section, described by Popov et al. (2011) as Billingsella aff. seletensis Nikitin, 1956; however, the new species differs in having an almost flat, transverse ventral profile and finer radial ornamentation.

Another similar species is Hyrcanostrophia lingulaeformis (Nikitin, 1956) from the Kuyandy Formation of the Boshchekul region, north-eastern Central Kazakhstan. However, the Iranian shells can be easily distinguished from the Kazakhstanian species in having a lower ventral interarea, finer and more even radial ornament, in lacking a dorsal median sulcus, and in having a smaller ventral muscle field that does not extend to mid valve.

Hyrcanostrophia tuyehensis differs strongly from Billingsella? fortis sp. nov., which is another species that commonly occurs in Member 3 of the Mila Formation, in having a convexoplane shell lacking dorsal median sulcus, in having a fine radial ornament and rudimentary socket ridges.

\section{Family Tritoechiidae Ulrich \& Cooper, 1936}

\section{Genus Darvaretoechia gen. nov.}

Derivation of name. - After Darvar village in Alborz Mountains, northern Iran.

Type species. - Billingsella costata Zhan, Jin, Rong, Zhu \& Han, 2010 from the Cambrian (Furongian) Guole Formation of Jiangxi Province, South China.
Table 3. Basic statistics of 10 articulated shells of Darvaretoechia prisca gen. et sp. nov.; sample M4/3TD.

\begin{tabular}{lccccccccc}
\hline & $\mathrm{Lv}$ & $\mathrm{Ls}$ & $\mathrm{W}$ & $\mathrm{T}$ & $\mathrm{Iw}$ & $\mathrm{Lv} / \mathrm{W}$ & $\mathrm{Ld} / \mathrm{W}$ & $\mathrm{T} / \mathrm{Lv}$ & $\mathrm{Iw} / \mathrm{W}$ \\
\hline $\mathrm{n}$ & 10 & 10 & 10 & 8 & 10 & 10 & 10 & 8 & 8 \\
$\mathrm{x}$ & 8.0 & 7.3 & 9.8 & 3.3 & 9.5 & $81.6 \%$ & $74.7 \%$ & $43.7 \%$ & $96.3 \%$ \\
$\mathrm{~s}$ & 1.6 & 1.3 & 1.9 & 0.6 & 1.8 & 6.9 & 6.0 & 4.9 & 4.7 \\
$\min$ & 5.2 & 4.9 & 7.5 & 2.5 & 7.5 & $69.3 \%$ & $65.3 \%$ & $35.4 \%$ & $86.7 \%$ \\
$\max$ & 10.3 & 9.2 & 12.7 & 4.2 & 12.7 & $89.8 \%$ & $81.5 \%$ & $48.6 \%$ & $100.0 \%$ \\
\hline
\end{tabular}

Diagnosis. - Shell ventribiconvex. Ventral valve with high, planar, strongly apsacline to orthocline ventral interarea; dorsal interarea low, planar, anacline with convex chilidium. Ventral interior with transverse teeth supported by thin, short, divergent dental plates. Ventral muscle field mainly within delthyrial cavity, open anteriorly. Ventral adductor muscle scars, wide, triangular, longer than diductor scars. Ventral mantle canal system saccate with subparallel vascula media. Dorsal interior with simple, ridge-like cardinal process bisecting low notothyrial platform, and with short, transverse socket ridges and low median ridge.

Remarks. - Darvaretoechia differs from Billingsella in having well developed dental plates, a low, weakly impressed ventral muscle field open anteriorly, short, curved socket ridges, and a low notothyrial platform that is not strongly inclined anteriorly. The presence of true dental plates indicates that Darvaretoechia can be considered as an early representative of the Family Tritoechiidae (for further discussion see Popov et al. 2001).

Eosotrematorthis Wang, 1955 has distinct dental plates and for this reason it is considered here within the Family Tritoechiidae. It differs from Darvaretoechia in having an apsacline ventral interarea, small, subquadrate ventral muscle field, a low ventral median ridge in front of the adductor muscle scars and rod-like socket ridges.

Species assigned. - Apart from the type species, only Darvaretoechia prisca sp. nov. can be assigned to the new genus.

\section{Darvaretoechia prisca sp. nov.}

Figures 4P, 5, 6; Table 3

Derivation of name. - After Latin priscus, ancient, early, former.

Holotype. - NMGW 2011.16G.307, conjoined valves from Cambrian, Furongian, Mila Formation (Member 4), sample Mila 4/3TD, Tuyeh-Darvar section, Alborz Mountains, Iran.

Paratypes. - 16 articulated shells (NMGW 2011.16G.308 to 323 ); 10 ventral valves (NMGW 2011.16G.324 to 343); 
13 dorsal valves: NMGW 2011.16G.344 to 355, 461. In total, comprising 17 articulated shells, 10 ventral and 13 dorsal valves; locality the same as for the holotype.

Diagnosis. - Ventribiconvex shell about four-fifths as long as wide, with almost orthocline ventral interarea and radial ornament with 8-11 strong, angular, primary ribs separated by wide interspaces, with up to 28 ribs in total. No capillae in interspaces between ribs.

Description. - Shell slightly ventribiconvex, about $44 \%$ as thick as long, subrectangular, about $82 \%$ as long as wide, with maximum width at, or slightly anterior to hinge line. Cardinal extremities from slightly acute to almost right-angled. Anterior commissure rectimarginate to very gently unisulcate (Fig. 5D, E). Ventral valve moderately convex with maximum depth at about one-third valve length from posterior (Fig. 5C, I). Ventral interarea planar, high, triangular, almost orthocline with narrow, convex pseudodeltidium completely covering delthyrium (Figs 5B, G, L). Dorsal valve gently convex with low, planar, anacline interarea. Dorsal sulcus very shallow, originating at umbo and gradually fading anteriorly. Radial ornament unequally costellate with 8-11 strong, angular, primary ribs separated by wide interspaces occupied by two generations of finer costellae inclined between primary ribs. Specimens about $8 \mathrm{~mm}$ long have $18-23$ ribs, whereas specimens $9-10 \mathrm{~mm}$ long have up to 28 ribs. Concentric ornament of fine regular filae, about 10 to 12 per $1 \mathrm{~mm}$ (Fig. 5).

Ventral interior with strong transverse teeth supported by thin dental plates (Fig. 6). Dorsal interior with low notothyrial platform bisected by simple, ridge-like cardinal process, short, transverse, curved socket ridges and low median ridge bisecting adductor muscle field.

Remarks. - This species differs from the type species Darvaretoechia costata (Zhan et al., 2010) in having an almost orthocline ventral interarea, in the complete absence of capillae between ribs, and in having coarser concentric fila and less numerous ribs, not exceeding 28 in mature specimens.

Order Pentamerida Schuchert \& Cooper, 1931

Suborder Syntrophiidina Ulrich \& Cooper, 1936

Superfamily Syntrophioidea Ulrich \& Cooper, 1936

Remarks. - Here we retain the Superfamily Syntrophioidea Ulrich \& Cooper, 1936 as a separate taxon and we do not consider it as a junior synonym of the Superfamily Porambonitoidea as suggested by Carlson (2002); see also the revision of Porambonites by Popov et al. (2005).
Family Tetralobulidae Ulrich \& Cooper, 1936

Subfamily Syntrophopsinae Ulrich \& Cooper, 1936

\section{Genus Palaeostrophia Ulrich \& Cooper, 1936}

Type species. - Syntrophia orthia Walcott, 1905; lower Chaomidian Series (formerly called Chaumitien Limestone, upper Furongian); Jinan, Shandong Province, North China.

\section{Palaeostrophia cf. orthia (Walcott, 1905)}

Figure 7A-J

Material. - Sample M2D; conjoined valves (NMGW 2011.16G.246); four dorsal valves [NMGW 2011.16G.240 $(\mathrm{L}=8.6, \mathrm{~W}=10.8, \mathrm{~T}=4.0, \mathrm{Sw}=4.6), 241(\mathrm{~L}=8.3$, $\mathrm{W}=11.4, \mathrm{~T}=3.5, \mathrm{Sw}=4.2), 242 ; 245(\mathrm{~L}=8.3, \mathrm{~W}=12.4$, $\mathrm{T}=4.2, \mathrm{Sw}=7.2)]$; three ventral valves $[\mathrm{NMGW}$ 2011.16G.243 ( $\mathrm{L}=8.6, \mathrm{~W}=12.0, \mathrm{Sw}=8.2), 244(\mathrm{~L}=8.9$, $\mathrm{W}=12.2, \mathrm{Sw}=6.2), 245]$.

Remarks. - These specimens are closely similar to the types of Palaeostrophia orthia (Walcott, 1905), originally described from the upper part of the Furongian (Cambrian) of the Shandong Province, North China; both taxa have a strongly transversely suboval, dorsibiconvex shell with a relatively narrow, sharply defined ventral sulcus, originating at the umbo and terminating as a high, semioval tongue; the dorsal median fold is high, originating at $1.5-2 \mathrm{~mm}$ from the umbo and defined laterally by angular plications (Fig. 7). The provisional attribution of the Iranian shells to this species is mainly due to the inadequate knowledge of the topotypes, which require revision. The species was described originally by Walcott $(1905,1912)$ as Syntrophia orthia, but he does not provide a description or illustration of the valve interiors. Subsequently, Ulrich \& Cooper (1938, pl. 41B, figs 13,14 ) illustrated the dorsal valve interior of one of the paratypes, proving its affiliation to Palaeostrophia; however, the ventral valve interior remains unknown.

Popov et al. (2011) recently described the Iranian Palaeostrophia shahrudensis from the Mila Formation Member 4 of Deh-Molla, Eastern Alborz. It differs from Palaeostrophia cf. orthia in having a less transverse, sub-rhomboidal shell with a dorsal median fold becoming prominent only at valve mid length.

\section{Palaeostrophia tecta Nikitin \& Popov, 1983}

Figure 7K-U, Table 4

1983 Palaeostrophia tecta Nikitin \& Popov; p. 130, pl. 33, figs $13-15$, text-fig. 2.

2001 Palaeostrophia tecta Nikitin \& Popov. - Holmer et al., p. 158, pl. 49, figs 12-15. 

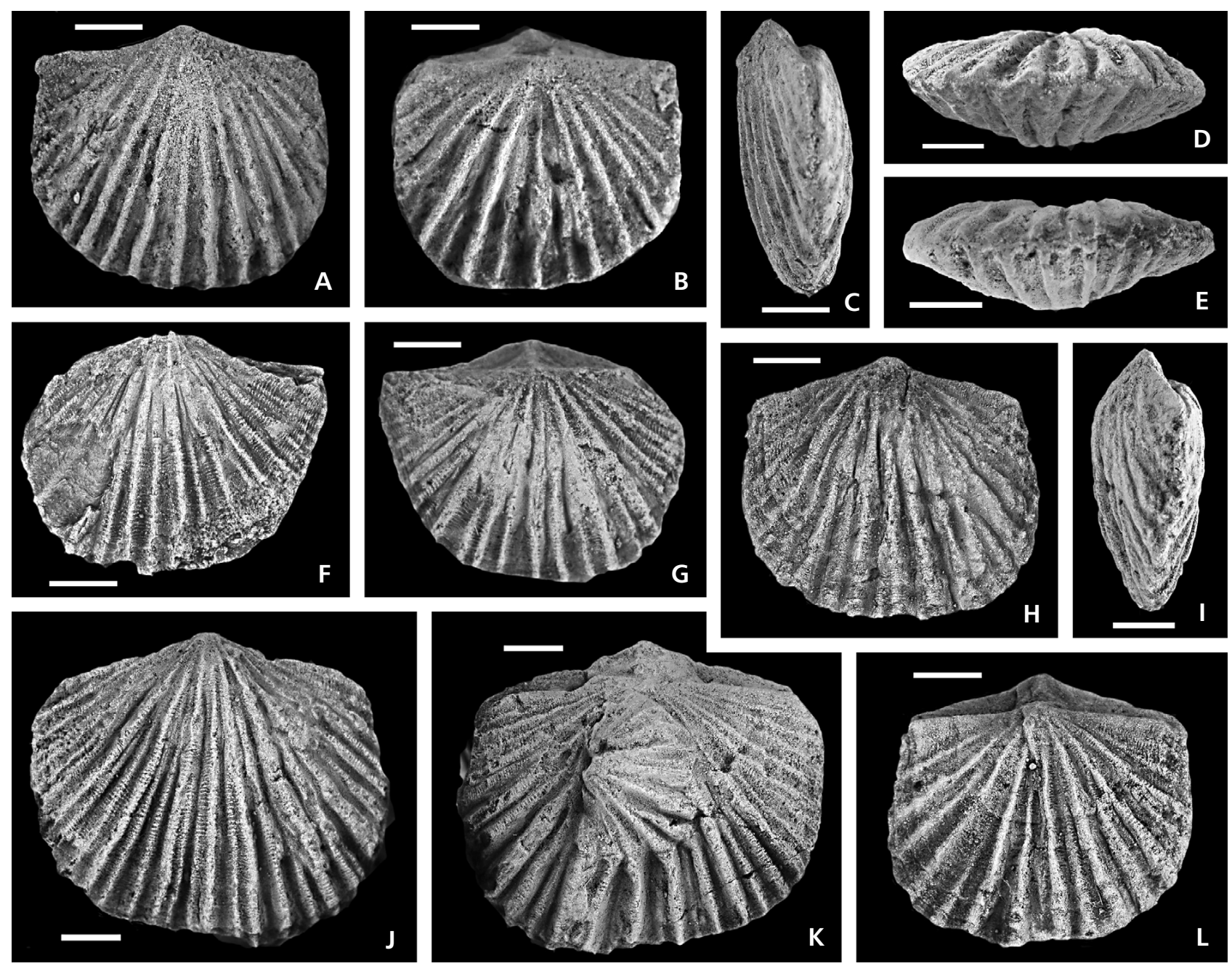

Figure 5. Darvaretoechia prisca gen. et sp. nov.; sample M4/3TD. • A-D - NMW 2011.16G.311, holotype, ventral, dorsal lateral and anterior views of conjoined valves. • E-G - NMW 2011.16G.308, anterior, ventral and dorsal views of conjoined valves. • H, I, L - NMW 2011.16G.309, ventral, lateral and dorsal views of conjoined valves. $\bullet$ J, K - NMW 2011.16G.311, ventral and dorsal views of conjoined valves. All scale bars are $2 \mathrm{~mm}$.
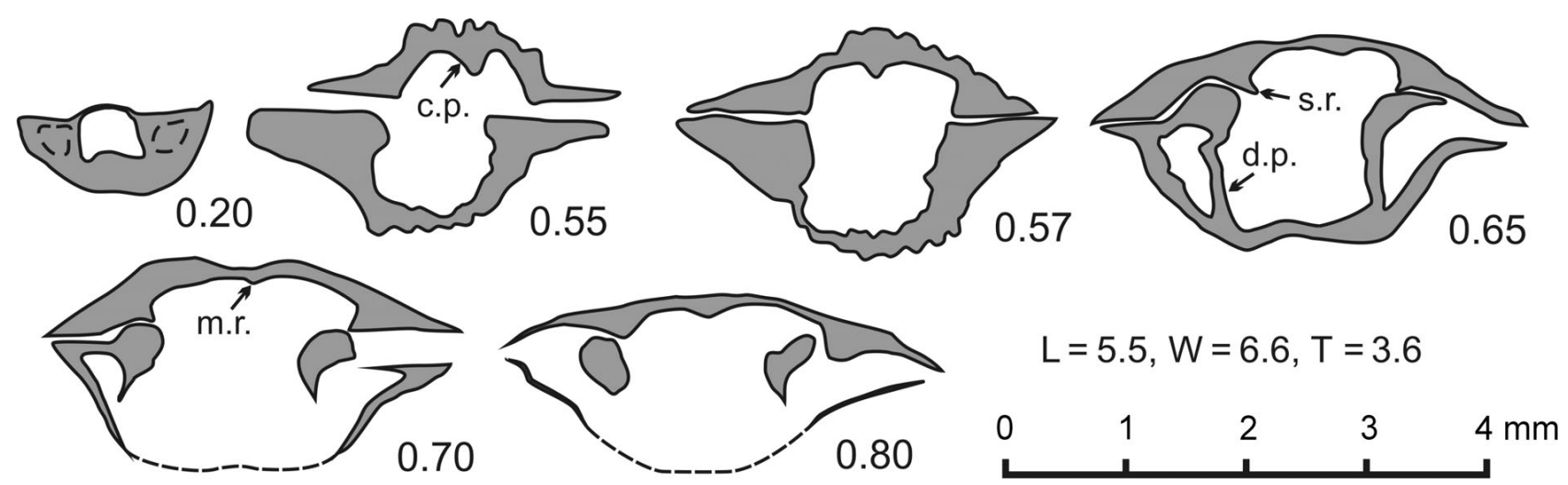

Figure 6. Transverse serial sections of Darvaretoechia prisca sp. nov.; sample M4/3TD.

Material. - Sample M4/3TD, 33 articulated valves (NMGW 2011.16G.255 to $285,306,307)$ seven ventral valves (NMGW 2011.16G.286 to 292), 12 dorsal valves (NMGW
2011.16G.293 to 305); sample M8D three dorsal valves: NMW 2011.16G.455 to 457; sample M10D, ventral valve (NMW 2011.16G.453), dorsal valve (NMW 2011.16G.454). 

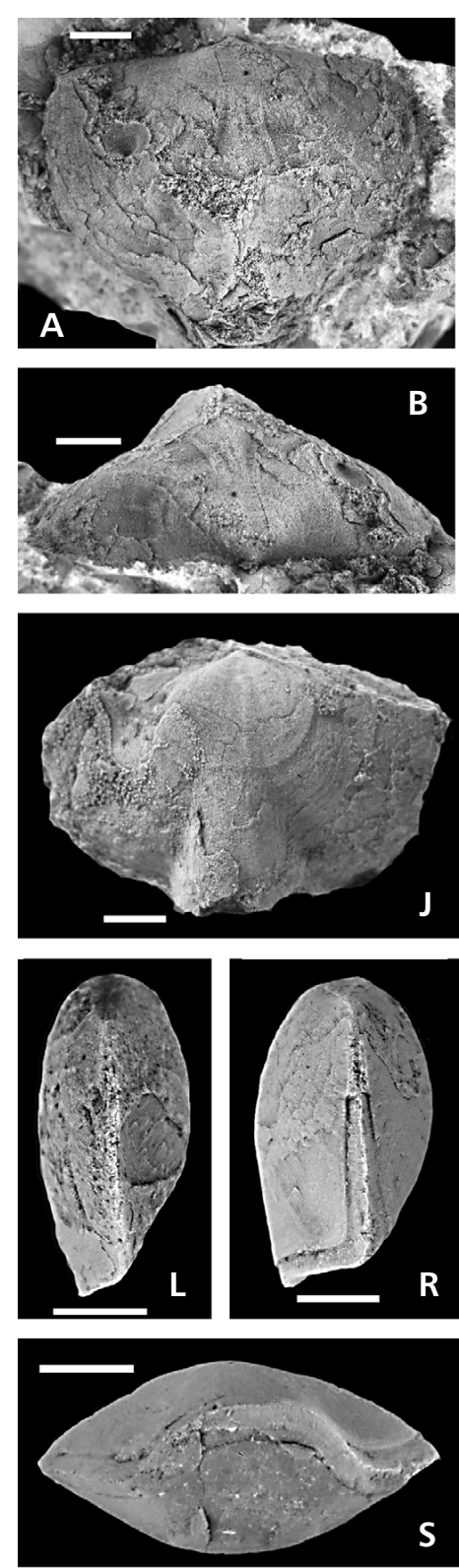
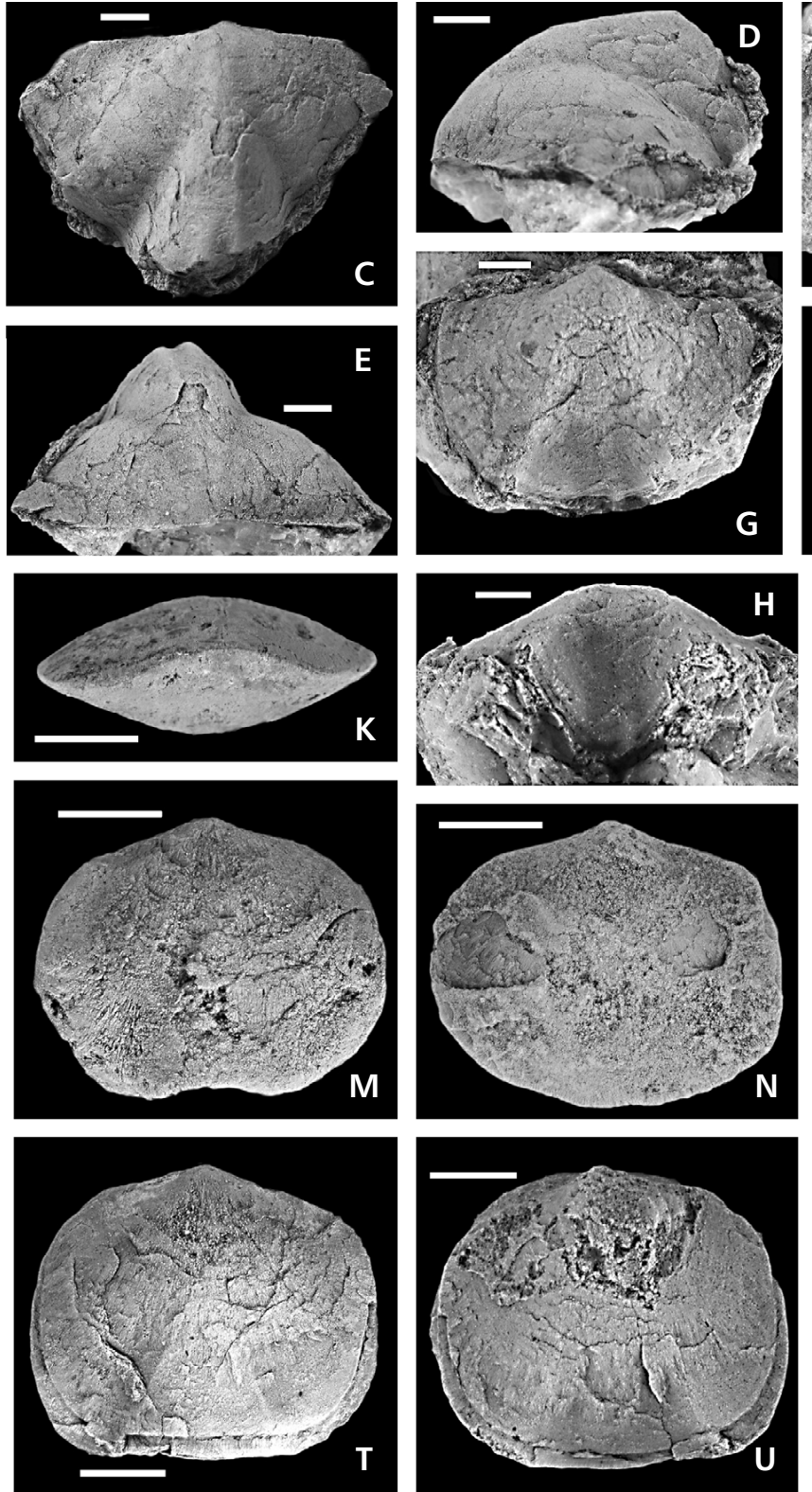
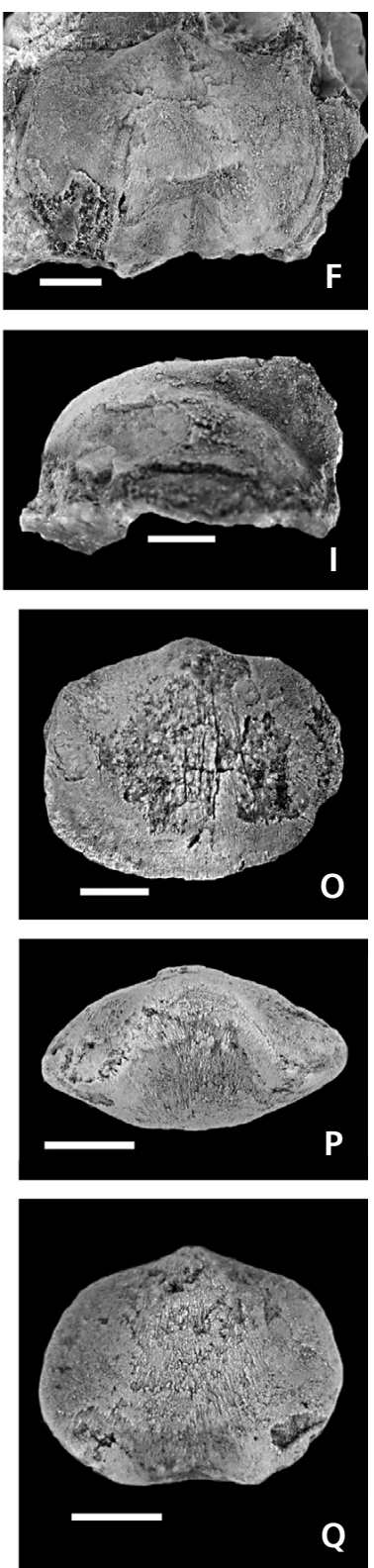

Figure 7. A-J - Palaeostrophia cf. orthia (Walcott, 1905); sample M2D. • A, B - NMGW 2011.16G.241, dorsal valve exterior, posterior view. - C-E - NMGW 2011.16G.245, dorsal valve exterior, lateral and posterior views. • F - NMGW 2011.16G.242, ventral valve exterior. • G, H - NMGW 2011.16G.244, ventral valve exterior and anterior view. • I, J - NMGW 2011.16G.245, dorsal valve side view, exterior. $\bullet$ K-U - Palaeostrophia tecta Nikitin \& Popov, 1983; sample M4/3TD; K-N - NMGW 2011.16G.255, anterior, lateral, dorsal and ventral views of conjoined valves, O-Q - NMGW 2011.16G.256, dorsal, anterior and ventral views of conjoined valves, R-U - NMGW 2011.16G.257, lateral, anterior, dorsal and ventral views of conjoined valves. All scale bars are $2 \mathrm{~mm}$.

Description. - Shell smooth, slightly dorsibiconvex, transverse, suboval in outline, about $84 \%$ as long as wide and $55 \%$ as thick as long. Hinge line short, slightly exceeding half maximum shell width. Anterior commissure broadly unisulcate. Ventral valve lateral profile moderately convex with maximal height slightly posterior to mid length. Incipient ventral interarea with small, open, triangular delthyrium. Broad ventral sulcus variably developed, originating slightly posterior to valve mid length, becoming prominent only near anterior margin of mature shells and terminating in a broad, semioval tongue, extending about two thirds total valve width. Dorsal valve moderately and evenly convex with broad median fold, semioval in cross section, weakly defined laterally and originating near valve mid length. Ventral interior with sessile spondylium. Dorsal interior with short hinge plates merging at bottom of notothyrial cavity.

Remarks. - These specimens are closely comparable with 
Table 4. Basic statistics of 19 articulated shells of Palaeostrophia tecta Nikitin \& Popov, 1983; sample M4/3TD.

\begin{tabular}{lcccccccccc}
\hline & $\mathrm{Lv}$ & $\mathrm{Ls}$ & $\mathrm{W}$ & $\mathrm{T}$ & $\mathrm{Sw}$ & $\mathrm{St}$ & $\mathrm{Lv} / \mathrm{W}$ & $\mathrm{Ld} / \mathrm{W}$ & $\mathrm{T} / \mathrm{Lv}$ & $\mathrm{Sw} / \mathrm{W}$ \\
\hline $\mathrm{n}$ & 19 & 19 & 19 & 19 & 19 & 19 & 19 & 19 & 19 & 19 \\
$\mathrm{x}$ & 6.8 & 6.8 & 8.1 & 3.7 & 5.4 & 1.9 & $83.7 \%$ & $83.2 \%$ & $54.9 \%$ & $66.9 \%$ \\
$\mathrm{~s}$ & 1.05 & 1.02 & 1.24 & 0.59 & 0.91 & 0.50 & 4.0 & 4.2 & 5.4 & 6.7 \\
$\min$ & 5.2 & 5.2 & 6.6 & 2.9 & 4.0 & 0.8 & $76.8 \%$ & $74.7 \%$ & $47.1 \%$ & $59.5 \%$ \\
$\max$ & 10.2 & 10.1 & 12.0 & 5.4 & 7.8 & 2.6 & $92.3 \%$ & $92.3 \%$ & $68.7 \%$ & $80.5 \%$ \\
\hline
\end{tabular}

the topotypes of Palaeostrophia tecta from the uppermost Furongian Euloma limatari-Taoyuania Beds of the Batyrbai section in the Malyi Karatau Range, Kazakhstan (Nikitin \& Popov 1983, Holmer et al. 2001) in having a slightly dorsibiconvex shell, with a broad dorsal fold and ventral sulcus with a semioval cross section, originating near valve mid length, as well as short hinge plates, merging at the bottom of the notothyrial cavity. The only slight difference is that the Iranian specimens have a less strongly swollen dorsal umbonal region.

\section{Acknowledgements}

Leonid Popov acknowledges support from the National Museum of Wales and the Payam-Noor University for work in Iran. Mohammad-Reza Kebria-ee Zadeh thanks the PayamNoor University for support via a research fellowship. Mansoureh Ghobadi Pour thanks the National Museum of Wales for logistical support on her visits to Cardiff; her work in Iran is supported by the Golestan University. Lars Holmer's work is supported by the Swedish Research council (VR). Constructive reviews from two anonymous reviewers improved the manuscript.

\section{References}

Bassett, M.G., Popov, L.E. \& Holmer, L.E. 2002. Brachiopods: Cambrian-Tremadoc precursors to Ordovician radiation events, 13-23. In Crame, J.A. \& Owen, A.W. (eds) Palaeobiogeography and biodiversity change: a comparison of the Ordovician and Mesozoic-Cenozoic radiations. Geological Society of London, Special Publication 194.

Bell, W.C. \& Ellinwood, H.L. 1962. Upper Franconian and Lower Trempealeauan Cambrian trilobites and brachiopods, Wilberns Formation, central Texas. Journal of Paleontology $36,385-423$.

CARLson, S.J. 2002. Syntrophiidina, 929-960. In KAESLER, R.L. (ed.) Treatise on Invertebrate Paleontology. Part H. Brachiopoda (revised), 4, Rhynchonelliformea (part). Geological Society of America \& University of Kansas Press, Boulder \& Lawrence.

CoOPER, G.A. 1952. New and unusual species of brachiopods from the Arbuckle Group in Oklahoma. Smithsonian Miscellaneous Collections 117, 1-35.

Endo, R. \& Resser, C.E. 1937. The Sinian and Cambrian Forma- tions and fossils of southern Manchoukuo. Manchurian Science Museum Bulletin 1, 1-474.

Freeman, R.J. \& StitT, J.H. 1996. Upper Cambrian and lowest Ordovician articulate brachiopods from the Arbuckle and Wichita Mountains, Oklahoma. Journal of Paleontology 70, 355-372.

Hall, J. 1863. Contributions to Palaeontology. Annual report of the Regents of the University of the State of New York on the condition of the State Cabinet of Natural History 16, 3-226.

Hall, J. \& Clarke, J.M. 1892. An introduction to the study of the genera of Palaeozoic Brachiopoda. Natural History of New York, Palaeontology 8, part 1. 367 pp. New York Geological Survey, Charles van Benthuysen \& Sons, Albany. DOI 10.5962/bhl.title.49071

HavlíčeK, V. 1971. Brachiopodes de l'Ordovicien du Maroc. Notes et Mémoires du Service Géologique du Maroc 230, $1-135$.

Holmer, L.E., Popov, L.E., Koneva, S.P. \& Bassett, M.G. 2001. Cambrian-early Ordovician brachiopods from Malyi Karatau, the western Balkhash Region, and northern Tien Shan, Central Asia. Special Papers in Palaeontology 65, 1-180.

Hosseini, H.K., LASEmi, Y. \& JAHANI, D. 2010. Depositional environment and sequence stratigraphy of the members 3,4 and 5 of the Mila Formation in the Hasanak-dar, Central Alborz. The $1^{\text {st }}$ International Applied Geological Congress, Department of Geology, Islamic Azad University - Mashad Branch, Iran, 26-28 April 2010, 1522-1527.

Hughes, N.C., Myrow, P.M., McKenzie, N.R., Harper, D.A.T., Bhargava, O.N., Tangri, S.K., Ghalley, K.S. \& Fanning, C.M. 2010. Cambrian rocks and faunas of the Wachi La, Black Mountains, Bhutan. Geological Magazine 148, 351-379. DOI 10.1017/S0016756810000750

Kobayashi, T. 1933. Upper Cambrian of the Wuhutsui Basin, Liaotung, with special reference to the limit of the Chaumitien (or Upper Cambrian) of eastern Asia, and its subdivision. Japanese Journal of Geology and Geography 11, $55-155$.

LASEMi, Y. \& Amin-Rasouli, H. 2007. Archaeocyathan buildups within an entirely siliciclastic succession: New discovery in the Toyonian Lalun Formation of northern Iran, the ProtoPaleotethys passive margin of northern Gondwana. Sedimentary Geology 201, 302-320.

DOI 10.1016/j.sedgeo.2007.05.015

MansuY, H. 1915. Faunes cambriennes du Haut-Tonkin. Mémoires du Service Géologique de l'Indo-Chine 4, 1-35.

Nikitin, I.F. 1956. Brakhiopody kembriia i ordovika Centralnogo Kazakhstana. 143 pp. Izdatelstvovo Akademii nauk KazSSR, Alma-Ata. 
Nikitin, I.F. \& Popov, L.E. 1983. Zamkovyie brakhiopody iz verkhnego kembriia i nizhnego ordovika Malogo Karatau, 124-135. In Apollonov, M.K., BANDAletov, S.M. \& IvShin, N.K. (eds) Stratigrafiia i paleontologiia nizhnego paleozoia Kazakhstana. Nauka, Alma-Ata.

Peng, S., Geyer, G. \& Hamdi, B. 1999. Trilobites from the Shahmirzad section, Alborz Mountains, Iran: Their taxonomy, biostratigraphy and bearing for international correlation. Beringeria 25, 3-66.

Popov, L.E., Egerquist, E. \& Zuykov, M.A. 2005. Ordovician (Arenig-Caradoc) syntrophiidine brachiopods from the East Baltic region. Palaeontology 48, 739-761. DOI 10.1111/j.1475-4983.2005.00487.x

Popov, L.E., Ghobadi Pour, M., Hosseini, M. \& Holmer, L.E. 2009. Furongian linguliform brachiopods from the Alborz Mountains, Iran. Memoirs of the Association of Australasian Palaeontologists 37, 103-122.

Popov, L.E., Ghobadi Pour, M., Kebria-Ee Zadeh, M.-R. \& Shanbeik, S. 2011. First record of silicified Cambrian (Furongian) rhynchonelliform brachiopods from the Mila Formation, Alborz Range, Iran. Memoirs of the Association of Australasian Palaeontologists 42, 193-207.

Popov, L.E., VinN, O. \& NikitinA, O.I. 2001. Brachiopods of the redefined family Tritoechiidae from the Ordovician of Kazakhstan and South Urals. Geobios 32, 131-155. DOI 10.1016/S0016-6995(01)80057-7

SCHUCHERT, C. 1893. A classification of the Brachiopoda. American Geologist 11, 141-167.

Schuchert, C. \& CoOper, G.A. 1931. Synopsis of the brachiopod genera of the suborders Orthoidea and Pentameroidea, with notes on the Telotremata. American Journal of Science 22, 241-251. DOI 10.2475/ajs.s5-22.129.241
Schuchert, C. \& Cooper, G.A. 1932. Brachiopod genera of the suborders Orthoidea and Pentameroidea. Memoirs of the Peabody Museum of Natural History 4, 1-270.

Severgina, L.G. 1967. New species and genera of Ordovician brachiopods from the Sayany-Altai Mountainous Region. Uchenye zapinski Tomskogo gosudarstvennogo universiteta 63, 120-140.

ShumARD, B.F. 1860. Descriptions of five new species of Gastropoda from the Coal Measures of a brachiopod from the Potsdam sandstone of Texas. Transactions of the Academy of Science of St Louis 1, 624-627.

Stöcklin, J., RutTner, A. \& NABAvi, M.N. 1964. New data on the Lower Palaeozoic and Precambrian of North Iran. Geological Survey of Iran, Reports 1, 1-29.

Ulrich, E.O. \& CoOPER, G.A. 1936. New genera and species of Ozarkian and Canadian brachiopods. Journal of Paleontology 10, 616-631.

Ulrich, E.O. \& CoOPER, G.A. 1938. Ozarkian and Canadian Brachiopoda. Geological Society of America, Special Paper $13,1-323$.

WalcotT, C.D. 1905. Cambrian Brachiopoda with descriptions of new genera and species. United States National Museum Proceedings 28, 227-337. DOI 10.5479/si.00963801.1395.227

WaLcotT, C.D. 1912. Cambrian Brachiopoda. Monographs of the United States Geological Survey 51(I+II), $872+363$ pp.

WANG, Y. 1955. New genera of brachiopods. Acta Palaeontologica Sinica 3, 83-114.

Zhan, R.-B., Jin, J., Rong, J.-Y., Zhu, X.-J. \& Han, N.-R. 2010. Late Cambrian brachiopods from Jingxi, Guangxi Province, South China. Alcheringa 34, 99-133.

DOI 10.1080/03115510903522872 